\title{
Exploring "Speak-O-Rama" as a Public Speaking Module: A Pilot Study in an Islamic Integrated Primary School
}

\author{
Nurul Iman Ahmad Bukhari (Corresponding author) \\ Centre for Language Studies and Generic Development, Universiti Malaysia Kelantan, 16100 Kota Bharu, Kelantan, Malaysia \\ E-mail: iman@umk.edu.my \\ Suhaida Omar \\ Centre for Language Studies and Generic Development, Universiti Malaysia Kelantan, 16300 Bachok, Kelantan, Malaysia \\ E-mail: suhaida.o@umk.edu.my \\ Atirah Izzah Che Abas \\ Centre for Language Studies and Generic Development, Universiti Malaysia Kelantan, 16100 Kota Bharu, Kelantan, Malaysia \\ E-mail: atirah@umk.edu.my \\ Bazilah Raihan Mat Shawal \\ Centre for Language Studies and Generic Development, Universiti Malaysia Kelantan, 16300 Bachok, Kelantan, Malaysia \\ E-mail: bazilah@umk.edu.my \\ Wan Suzanna Aafanii Adeeba Wan Ibrahim \\ Centre for Language Studies and Generic Development, Universiti Malaysia Kelantan, 16300 Bachok, Kelantan, Malaysia \\ E-mail: suzanna@umk.edu.my \\ Ariezal Afzan Hassan \\ Centre for Language Studies and Generic Development, Universiti Malaysia Kelantan, 16300 Bachok, Kelantan, Malaysia \\ E-mail: ariezal@umk.edu.my \\ Noor Hisham Md Nawi \\ Centre for Language Studies and Generic Development, Universiti Malaysia Kelantan, 16300 Bachok, Kelantan, Malaysia \\ E-mail: hisham@umk.edu.my
}

Received: 10-10-2016

Published: 01-03-2017
Accepted: 07-12-2016

doi:10.7575/aiac.ijalel.v.6n.2p.249
Advance Access Published: January 2017

URL: http://dx.doi.org/10.7575/aiac.ijalel.v.6n.2p.249

The research is financed by the Short Term Grant Scheme (SGJP) under Universiti Malaysia Kelantan.

\begin{abstract}
This paper describes the pilot study in implementing a public speaking module for a primary school level. The module development was structured according to ASSURE Model with the Communicative Language Teaching (CLT) as the basis used in designing the module activities. One group of Year 4 students from an Islamic integrated school was selected and the research method employed was the quasi-experimental research with pre and post-tests as well as interviews with the English teachers on the students' performance and self-confidence. Students were also interviewed to identify their self confidence level before and after the implementation of the public speaking module. This research project is hoped to increase students' oral proficiency along with increasing self-confidence in public speaking at a young age, and to propose the implementation of this module as reference in primary education.
\end{abstract}

Keywords: public speaking, primary school, oral proficiency, self-confidence, CLT

\section{Introduction}

Communicative Language Teaching (CLT) has been adapted in the English language teaching methods in schools throughout Malaysia and the main focus of this method is written and oral production. Written production is fairly supported with sufficient resources of reading materials in school; however, oral production is a challenge where listening input is significantly dependent on guidance from the English teachers. In this stance, English teachers who have difficulties in providing listening and speaking input for oral production require additional support where 
instructional materials is concerned. In the case of Islamic integrated schools, they are still behind in empowering oral proficiency among students due to certain factors such as an integrated curriculum still in its developing stages (Maimun, 2015) and with less-trained English teachers (Ahmad Zabidi, 2005). Therefore, these schools are in need of organised instructional materials to fully guide its English teachers to deliver proper listening and speaking input to enhance students' oral production skills.

The aim of this research is to integrate the CLT principles in designing a public speaking module called 'Speak-ORama' to improve oral competency and self-confidence of students in a private Islamic integrated school. There are three pertinent research objectives, which are:

1) to develop a new module to enhance students' oral competency,

2) to assess students' proficiency in oral English through public speaking activities, and

3) to assess students' confidence in participating in public speaking activities

\subsection{The Conceptual Framework}

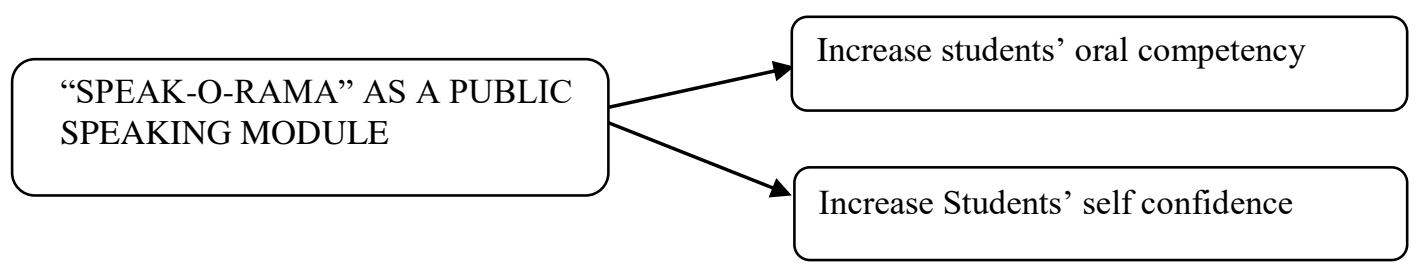

Figure 1. Conceptual Framework of the study

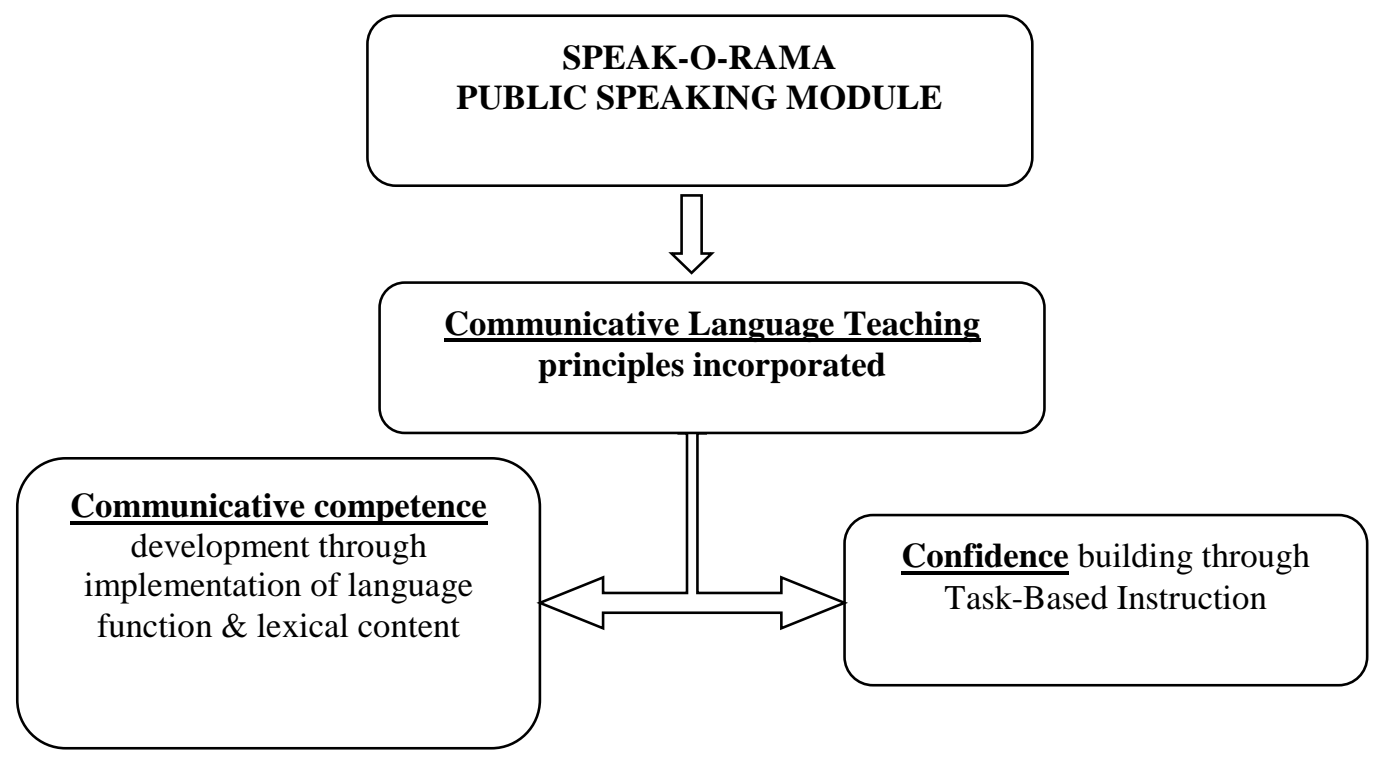

Figure 2. Conceptual Framework based on CLT

\subsection{Communicative Language Teaching}

Communicative approach in language teaching starts from a theory of language as communication. The goal of language teaching is to develop communicative competence (Richards and Rodger, 1999: 69). CLT is the name which was given to a set of beliefs which included not only a re-examination of what aspect of language to teach, but also in a shift in emphasis in how to teach. The "what to teach" aspect of the communicative approach stressed the significance of language function rather than focusing solely on grammar and vocabulary. A guiding principle was to train students to use these language forms appropriately in variety of context and for a variety of purposes.

The "how to teach aspect" of communicative approach is closely related to the idea that language learning will take care of itself and that abundant exposure to language in use and plenty of opportunities to use it are essentially important for students' development and skill (Harmer, 1998: 84). CLT aims to make communicative competence as the goal of language teaching and to develop techniques and procedures for teaching language skills that are based on interdependent aspects of language and communication. Despite all the 4 skills involved in CLT, this study focused on spoken communication which was through public speaking. 


\subsection{Public Speaking}

Public speaking refers to the speaker's action in which he/she, as the centre in the communication process, addresses the audience consecutively (Carlin, 1995). It is an indispensable part of human activities, such as students answering questions in class or demonstrating ideas on certain topics, teachers holding lectures, and, as in working environment, work reports, production releases and introductions, commercial negotiations, meeting addresses, discussions and communications as well as commenting on certain topics in daily life. In the context of this pilot study, public speaking is limited to individual oral presentation in front of the students' classmates and in the presence of both the teachers and researchers.

Speaking is one way to communicate ideas and thoughts orally. To enable students to communicate, we need to apply the language in real communication. According to Rickheit and Strohner (2008: 207), speaking is speech or utterances with the purpose of having intention to be recognized by speaker and the receiver processes the statements in order to recognize their intentions. Brown and Yule (1999:14) stated that speaking is depending on the complexity of the information to be communicated; however, the speaker sometimes finds it difficult to clarify what they want to say. Rebecca (2006:144) stated that speaking is the first mode in which children acquire language, it is part of the daily involvement of most people with language activities, and it is the prime motor of language change. It also provides our main data for understanding bilingualism and language contact.

In this study, a variety of instructional materials was provided to the students. This was based on Pagcaliwagan's (2015) report on the importance of instructional materials in teaching knowledge and reinforcing verbal instruction. Activities in training for public speaking include familiarity with the context of the topic to be presented. Indeed, materials in language teaching have roles as a resource for presentation of materials either spoken or written, as a source of activities for learners' practice and communicative interaction, as a reference source for learners on grammar, vocabulary, pronunciation and so forth, and as a source of stimulation and ideas for classroom activities (Richards,

2003).

\subsection{Self-Confidence}

Speaking skill is one of the most important skills required to be a good communicator. Fachrurrazy (2012) stated that speaking is a dynamic and active skill which mainly aims to convey thoughts and express ideas. Speaking skills is acquired during childhood since children at this stage are very receptive towards stimulus from surroundings (Harris, 2009). However, the mastery of such skill is an arduous task to endeavour especially amongst school students. It can be observed in Malaysian schools whereby students whom have undertaken English language as a compulsory subject are still unable to speak well. Al-Hebaish (2012) states that acquiring speaking skill is crucial for students at all levels to enhance their ability to be a competent communicator.

The main factor that drives students to speak well is self-confidence. It also determines how well students perform in social life as well as in their academic achievement. Bitterlin et. al (2011) explains that self-confidence is developed by mainly by life experience which involves parents, siblings, peers and educators. From such encounters, students learn about themselves and also the world around them. The encouragement, assistance and reassurance given to students will shape the inner feelings of students which eventually leads a high self-confidence level.

Tallon (2009) along with Torres \& Turner (2016) posit that language learning is a complex process that is heavily dependent on affective and cognitive factors which establish the main differences in students learning a second language success rate. Brown (2000) claims the affective domain is the emotional part in human behaviour which comprises of emotion, motivation, aptitude, anxiety and self-confidence. Of all these key tenets, self-confidence is the most vital variable which affects language learning. In addition, Dornyei (2005) also states that self-confidence is similar to self-esteem in which both determine students' perception of how good their abilities are. Other past researches on self-confidence have also used different terms such as self-evaluation, self-worth, self-appraisal and selfsatisfaction which are all interchangeable. These psychological terms define how an individual evaluates him or herself according to different values that result in different emotional states (Rubio, 2007).

Self-confidence in general is developed throughout students' childhood and is a product of intra and interpersonal experiences (Harris, 2009). Most studies conducted on self-confidence shows that positive experience or successful attempt to communicate is the key factor to heighten the development of self-confidence while negative experience such as failing to communicate will have negative effects on the students' confidence level growth. Home, school, friends and teachers are also very important for the progression of self-confidence as they are the medium to a successful and constructive language learning process (Pierce and Gardner 2004; Tallon, 2009; Torres and Turner 2016).

\subsection{Extrinsic Motivation}

This study which examined the effect of conducting a CLT based module to primary school students in order to increase their speaking proficiency has also extended its implication to the motivational aspect. Previous studies have shown that motivation is manifested mainly through the behaviours of the students, and in the context of second language learning a few types of motivation are proposed namely instrumental, integrative and from the cognitive perspective, intrinsic and extrinsic motivation become the main constructs (Dueñas and Vargas, 2013). These different types of motivation are experienced by the students at different levels or spectrum (Ryan and Deci, 2000). 
According to Brouse et al. (2010:1), motivation can be defined as the "urge or push to carry out a specific action or behaviour". In this study, the focus is on extrinsic motivation where "the behaviours that are extrinsically motivated are carried out as a means to an end rather than an end in itself" (Brouse et al., 2010).

There are different types of extrinsic motivation. Identified regulation is when an individual decides to perform an action because they perceive the action as necessary. When performing the action, no external pressure is present at the time as the action itself agrees with the individual's values. Introjected regulation is where an individual's action or behaviour is part of an attempt to avoid internal conflicts rather than driven by self-determination. External regulation is when a particular behaviour is performed due to the influence of external rewards and constraints (Fortier et al., 1995).

This study focuses on external regulation as the researchers' teaching approach becomes instrumental in promoting the students' extrinsic motivation. In this study, extrinsic motivation plays a significant role in justifying the changes of the students' behaviour pre and post introduction of the module in the classroom. According to Vilímec (2006), teacher's technique in the language classroom which constitutes of organising the activities, monitoring the students' performance, making sure students know what to practice and that they practice effectively is a critical factor concerning the students' motivation in learning English.

Although some researchers have argued that intrinsic motivation is more valued and everlasting than extrinsic motivation, past studies have also been proven that students need external incentives such as prizes, positive feedbacks, extra marks and etc. to ensure successful performance in language. This is further supported by Akey (2006:5) where in her study it is stated that "in the educational setting, students need incentives to perform, so one of the real situations that teachers must face is to provide students with tangible rewards".

\subsection{The ASSURE Model}

ASSURE is one of the most prominent Instructional System Design (ISD) models documented in the literature to date. According to Dabbagh (2002), ISD is a process which uses media-based "intervention" to aid the process to determine the current state of learners' comprehension and also helps to define the end objective of an instruction. The practice of ISD requires arranging media content such as text, images, animation/video and audio to help instructors to effectively support learners' learning process. ISD is mainly designed to increase the effectiveness and efficiency of instructions. In addition, ISD utilizes an array of interactive media to enhance face to face teaching methods and addresses learning objectives. Beetham \& Sharpe (2007) stated that the use of ISD which comprises of innovative e-learning approaches could help to innovate and support conventional teaching methods to be more engaging.

This current study used the ASSURE model which according to Gustafson \& Branch (2002), is one of the most classroom oriented models. It is highly used by instructors in schools and universities because it does not require the need for high complexity of the chosen media or technology and in-depth knowledge of selected field. The ASSURE model helps to bridge the gap between novice and experienced instructors by helping them to easily decide on the subject matter, relevant teaching methods and medium of delivery. The ASSURE model provides inexperienced instructors a guideline to ensure quality teaching and learning process are delivered to the students.

Heinich et. al (2001) stated that in order to use media technologies effectively, a systematic and extensive procedure is necessary. Hence, the use of ASSURE model is suggested which encompasses six major steps in an instructional planning process.

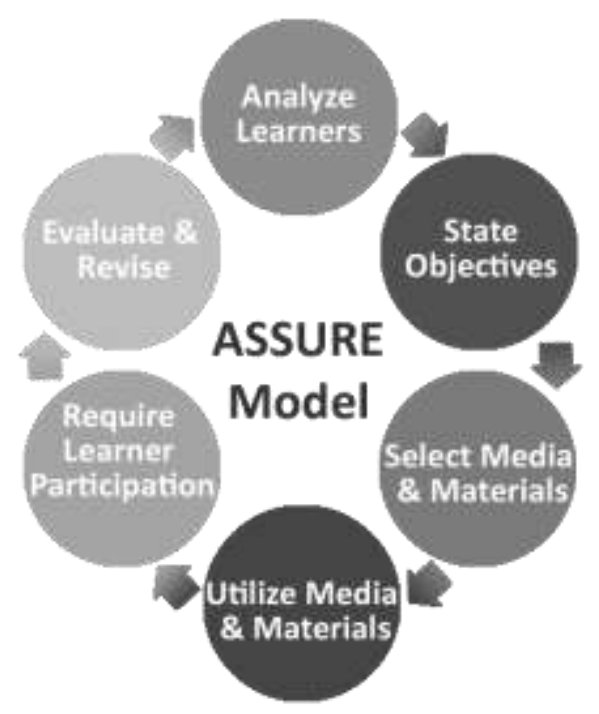

Figure 3. Flow Chart of the ASSURE model

The "Analyse Learners" stage focuses on the recognition of learners' characteristics and learning style preferences. The second stage of "State Objectives" requires the teacher to determine the learning objectives and outcomes. "Select Methods, Media and Materials" entails appropriate selection teaching approaches, media and materials. In the "Utilise 
Media and Material" stage, instructors must plan and implement the consumption of media to the students effectively. "Require Learner Participation" means that instructors should keep the students actively engaged during the process and finally the "Evaluate and Revise" stage refers to the instructor's assessment of teaching and lesson achievements (Heinich et. al, 2002). Specifically, Table 1 below describes how the ASSURE Model was utilised in this study.

Table 1. The ASSURE Model in developing Speak-O-Rama

\begin{tabular}{|c|c|c|}
\hline $\mathbf{A}$ & Analyse Learners & $\begin{array}{l}\text { Needs analysis of the an Islamic integrated primary school students are } \\
\text { conducted through interviews with the students' teachers. The level of } \\
\text { content required for the students are also analysed through thorough } \\
\text { scrutiny of the students' textbook. }\end{array}$ \\
\hline $\mathbf{S}$ & State Objectives & $\begin{array}{l}\text { The objectives are to enable students to increase oral competency in } \\
\text { English, and also gain confidence in speaking English in front of others. } \\
\text { This is to be achieved by incorporating CLT in the Speak-O-Rama } \\
\text { Module. }\end{array}$ \\
\hline $\mathbf{S}$ & $\begin{array}{l}\text { Select Methods, Media, } \\
\text { and Materials }\end{array}$ & $\begin{array}{l}\text { Methods and materials to be used for the module sessions are determined } \\
\text { so as to adhere with CLT priniples. }\end{array}$ \\
\hline $\mathbf{U}$ & $\begin{array}{l}\text { Utilize Methods, } \\
\text { Media, and Materials }\end{array}$ & $\begin{array}{l}\text { The Speak-O-Rama sessions will be conducted throughout a } 4 \text { week term } \\
\text { (not including the post-test) in } 4 \text { stages (refer to Table } 2 \text { ). Briefly, students } \\
\text { have to complete } 4 \text { speaking tasks in } 4 \text { weeks. }\end{array}$ \\
\hline $\mathbf{R}$ & $\begin{array}{ll}\text { Require } & \text { Learner } \\
\text { Participation } & \end{array}$ & $\begin{array}{l}\text { Students are required to participate in all drilling and speaking activities in } \\
\text { each session of the Speak-O-Rama Module }\end{array}$ \\
\hline $\mathbf{E}$ & Evaluate and Revise & $\begin{array}{l}\text { The effectiveness of the module will be assessed based on } 2 \text { variables: } \\
\text { 1) Students' oral competency will be gauged through assessment of oral } \\
\text { presentations before (pre-test) and after (post-test) the module treatment } \\
\text { 2) Students' confidence will be determined based on their feedback on } \\
\text { their experience in speaking in front of the class (from the beginning till } \\
\text { the end of the module) using interviews } \\
\text { From here, the module effectiveness in achieving the objectives is } \\
\text { determined. The Speak-O-Rama Module will then be revised for future } \\
\text { use. }\end{array}$ \\
\hline
\end{tabular}

\subsection{Islamic Integrated Schools}

For this study, it is essential to understand the type of school involved. One possible meaning of 'integrated' is the cojoining between Science and non-Science subjects, irrespective of the languages used or whether they are related to cocurricular or non-curricular activities (Maimun, 2015). Although these schools have the autonomy of developing their own integrated curriculum, they still follow the national curriculum, since their main function is to prepare students for the same examinations (Rahimah, 1998). Among the many other schools of its kind in Malaysia, the Islamic integrated school included in this study provides a viable solution for a holistic and integrated Islamic education system by offering parents and students the opportunity to choose between Islamic studies and professional fields (Md Obaydul Hoque et al., 2015)

\subsection{Past Studies}

According to Musa, Lie, and Azman, (2012), Malaysian schools focus more on acquiring two particular language skills namely writing and reading; mostly concentrating on the grammar components. Consequently, students learn the theoretical part of the language but have failed in communicating or practising the language in spoken or verbal contexts. Likewise, Baker and Westrup (2003) asserted that due to the nature of local, national or international examinations all around the world which give emphasis on the writing component, speaking skills are very often neglected. Teachers focus more on teaching grammar and vocabulary to enhance the writing skills and rarely stress on speaking skills. As a result, students are not able to speak proficiently. Due to the least attention given to speaking skills especially in schools, this study aimed to bridge the gap by developing a public speaking module focusing on primary school level.

A considerable amount of literature has been published on communicative language teaching method (CLT) using various tools that emphasise on speaking skills in school (Ampa et al., 2013; Efrizal, 2012; Endahaty and Purwanto, 2016; and Saputra and Wargianto, 2015). However by far, these research studies on CLT in schools were conducted in the Indonesian context, a neighbouring country to Malaysia. The literature on CLT in the Malaysian context focusing on school level, however, is scarce due to much attention having been given to improving communication skills at the tertiary level. At tertiary level, students already begin to realise the importance of mastering speaking skills which will increase their probability in securing good jobs. In the same vein, Baker and Westrup (2003: 5) proposed that "a student who can speak English well may have greater chance for further education, of finding employment and gaining promotion.” In a study on developing speaking skills module for engineering students in Universiti Malaysia Pahang, 
Radzuan et. al (2016) reported that there was a considerable improvement in students' proficiency as well as a significant reduction of communication apprehension level after implementing the speaking skills module.

Ampa et al. (2013) utilised the ASSURE model to develop contextual learning materials to be used in a speaking subject. The validity of the contextual learning materials developed was assessed from three aspects, namely psychological aspect, pedagogical aspect, and methodological aspect. The research instrument took a questionnaire type used to obtain data from 8 experts and analysed them quantitatively and qualitatively. It was found that the stages of the instructional design were suitable to produce the contextual learning materials for English speaking skills.

\section{Method}

\subsection{Sample Population and Instruments}

This research implemented the quasi-experimental approach. A number of 6 Year 4 students from a private Islamic integrated school, Sekolah Rendah Ugama Al-Hilal (SRUA) in Kota Bharu was selected by their teacher to participate in this study and considered as the experimental group in which they were given treatment using the proposed public speaking materials.

The design of the research is as follows:

Table 2. Quasi-experimental diagram

\begin{tabular}{lllllll}
\hline Group & Week1 & Week2 & Week3 & Week4 & Week5 \\
\hline Experimental Group (SRUA1) & Pre- & Treatment & Treatment & Treatment & Treatment & Post- \\
& test & 1 & 2 & 3 & 4 & test \\
\hline
\end{tabular}

Pre-tests and post-tests were conducted in the form of an individual oral presentation to assess English language proficiency. There were interviews with the English teachers on the students' performance and the usefulness of the materials. Students were also interviewed to identify their self confidence awareness before and after the exposure to the public speaking modules and activities. Results attained from the pre and post tests were recorded and analysed.

\subsection{Research Procedure}

The study examined the implementation of the Speak-O-Rama module over a term of 4 weeks which allowed the students to complete the four main topics under Speak-O-Rama. They went through the module along with their respective school classmates in the classroom; however, special attention was given to the 6 respondents of the study. This module was conducted once a week for 1 hour in the English lessons during the students' school time. Each session was handled by one English language teacher. Before the initial session, a pre-test in the form of an oral presentation was administered individually in discrete to gauge the oral competency of the student. After the 4th week Speak-O-Rama module, students gave an oral presentation in front of their class (post-test) to gauge their oral competency.

Interviews and presentations of participants were analysed for qualitative data. The four stages are as shown below:

Table 3. Stages of the Speak-o-Rama Module

\begin{tabular}{|c|c|c|c|}
\hline $\begin{array}{l}\text { Week/ } \\
\text { Topic }\end{array}$ & Session & Objective & Stage Outcome \\
\hline \multirow{3}{*}{$\begin{array}{l}1 \\
\text { My Family }\end{array}$} & Pre-test & & Oral presentation \\
\hline & $\begin{array}{l}\text { Drilling } \\
\text { (20 min.) }\end{array}$ & $\begin{array}{l}\text { - Students should be able to identify } 5 \\
\text { adjectives related to description of people. }\end{array}$ & \multirow{2}{*}{$\begin{array}{l}\text { Be able to speak } 2 \\
\text { sentences in front of the } \\
\text { class }\end{array}$} \\
\hline & $\begin{array}{l}\text { Speaking } \\
(20 \text { min.) }\end{array}$ & $\begin{array}{l}\text { - Students should be able to construct at least } 5 \\
\text { simple sentences about family. }\end{array}$ & \\
\hline \multirow[t]{2}{*}{$\begin{array}{l}2 \\
\text { My Friend }\end{array}$} & $\begin{array}{l}\text { Drilling } \\
(20 \text { min. })\end{array}$ & $\begin{array}{l}\text { - Students should be able to identify at least } 10 \\
\text { words related to moral values. }\end{array}$ & $\begin{array}{l}\text { Be able to recite } 1 \text { whole } \\
\text { paragraph in front of the class }\end{array}$ \\
\hline & $\begin{array}{l}\text { Speaking } \\
(40 \text { min. })\end{array}$ & $\begin{array}{l}\text { - Students should be able to construct at least } 8 \\
\text { simple/ compound sentences about a friend. }\end{array}$ & \\
\hline \multirow{2}{*}{$\begin{array}{l}3 \\
\text { My } \\
\text { Classroom }\end{array}$} & $\begin{array}{l}\text { Drilling } \\
\text { (20 min.) }\end{array}$ & $\begin{array}{l}\text { - Students should be able to describe at least } 5 \\
\text { items needed to decorate their classroom. }\end{array}$ & $\begin{array}{l}\text { Be able to recite } 2 \text { paragraphs } \\
\text { in front of the class }\end{array}$ \\
\hline & $\begin{array}{l}\text { Speaking } \\
(40 \text { min.) }\end{array}$ & $\begin{array}{l}\text { - Students should be able to construct at least } 8 \\
\text { simple/ compound sentences about decorating } \\
\text { their classroom. }\end{array}$ & \\
\hline \multirow{2}{*}{$\begin{array}{l}4 \\
\text { My } \\
\text { Ambition }\end{array}$} & $\begin{array}{l}\text { Drilling } \\
\text { (10 min.) }\end{array}$ & $\begin{array}{l}\text { - Students should be able to identify at least } 10 \\
\text { words related to occupations. }\end{array}$ & $\begin{array}{l}\text { Be able to to recite } 3 \\
\text { paragraphs in front of the class }\end{array}$ \\
\hline & $\begin{array}{l}\text { Speaking } \\
(50 \text { min. })\end{array}$ & $\begin{array}{l}\text { - Students should be able to construct at least } 8 \\
\text { simple/ compound sentences about their } \\
\text { ambition. }\end{array}$ & \\
\hline 5 & Post-test & & Oral presentation \\
\hline
\end{tabular}




\section{Results and Discussion}

The discussion section is arranged in accordance to the research objectives.

\subsection{To develop a new module to enhance students' oral competency}

The Speak-O-Rama module was developed based on the ASSURE Model in which the first step was to identify the students' oral competency and learning style preferences based on interviews with the teachers and respondents themselves. The content of the module was predetermined by the teachers as stated in their syllabus. Next, the main objective of the module was to assess students' public speaking skills which were later slightly focused on students' motivation and self-confidence based on the teachers' suggestions. The CLT principles were the guidelines in selecting methods, media, and materials where activities in the module were tailored to the syllabus topics and students' proficiency level. Media and materials used included cue cards, songs, pictures, sticky notes, and manila cards. Throughout the implementation of the module, the students were required to take part in group activities and guided oral presentations. The final stage of the development of the module involved interviewing students and teachers to revise the contents and approaches of the module. The findings revealed that the module was effective in helping students to be more vocal in oral presentations and it was a pleasant surprise when more students volunteered to participate in the last session of the module.

\subsection{To assess students' proficiency in oral English through public speaking activities}

Prior to this study, the English language teacher was interviewed to get the information on the students' background and performance as well as her teaching approaches in developing students' oral proficiency. This was also conducted to validate the teaching approaches practised by teachers before the implementation of the module. Interestingly, it was found that the teacher gave more emphasis on reading and writing skills than developing oral proficiency and pronunciation skills among the students, and that it was a common teaching approach among the other teachers as well. Teachers seem to use teacher-centred approach where voluntarism is scarcely encouraged. In this teacher-centred setting, teachers would have to call on names to participate in read aloud activities or to answer questions. It appeared that the students either did not have the opportunity to volunteer or they might have been used to such approach that they did not bother to volunteer.

In contrast, this study used learner-centred approach where the module was designed to incorporate active involvement from the whole students in the classroom. The activities in the module were established in a comfortable and low-threat learning environment; students become less anxious and more relaxed. Hence, more students voluntarily participated in the activities and their oral proficiency improved significantly. Based on the findings, it was found that students' level of proficiency increased week by week parallel with the length of text they delivered during the public speaking activities. This was observed in terms of language components such as vocabulary and the pronunciation they acquired and also the ability to use the vocabulary they learned from the module in appropriate context through guided exercises. This study found that students were able to perform all guided language tasks given consistently.

On the one hand this research aimed to identify whether or not the module was able to help increase the students' level of oral proficiency of the English language, and the finding has indicated that they showed some improvement gradually from the first to the last sessions. On the other hand, the use of this module has managed to increase the number of volunteers among the students which indicated that they have gained some self-confidence along the way.

\subsection{To assess students' confidence in participating in public speaking activities}

As stated earlier, this study also focused on students' self-confidence which was portrayed during the public speaking activities. The students' confidence was assessed through their voluntary participation in individual oral presentation. This module integrates drilling and guided oral presentation. Drilling activities consist of vocabulary games which emphasise on vocabulary acquisition and pronunciation. This module used realia, flash cards, and visual aids as teaching aids in teaching new vocabulary and pronunciation. During the drilling activities students were required to actively participate in groups. This study found that there was significant improvement in the students' self-confidence after this module was completed. They showed a gradual change from low self-confidence in the first session to high self-confidence in the last one. These activities provided an environment of trust and the sense of competitiveness as they have to complete the tasks given within the stipulated time and being rewarded with praises by their fellow classmates, teacher and researchers. This result correlated with Pierce and Gardner's (2004), Haris's (2009), Tallon (2009) and Torres and Turner's (2016) studies that positive behaviour which in this research referred to students' successfully participated in the oral presentations as well as the encouragement from the audience were among the factors that led to effective language learning and high self-confidence.

The attribute of self-confidence could be associated with motivation. This study has been able to demonstrate that as the students participated in more activities, they become more confident and motivated. Consequently, competitiveness promotes students' motivation to voluntarily participate in the oral presentations. The most interesting finding was that, at the end of this study, many students volunteered to deliver an individual oral presentation without prior preparation which showed that their confidence and motivation levels have increased significantly. The findings support the study from Dueñas and Vargas (2013) that providing competitive environment among the students encourages confidence in speaking. Besides that, they also stressed that teachers' technique in classroom is crucial as it promotes the students' extrinsic motivation which further influences the development of their speaking skill (Vilímec, 2006). 
Relevant to this study, the module introduced throughout the intervention has promoted the students' level of extrinsic motivation through the teaching techniques adopted as well as the rewards given in the form of compliments and materials which has consequently improved their oral proficiency as well as their confidence and motivation levels.

Furthermore, the module introduced in this study has adopted plenty of visual aids throughout the intervention. The use of sufficient visual aids in language classroom promotes students' extrinsic motivation. Adopting visual aids in language classroom encourages the students to talk at the presentation stage. Visual aids also motivate the students to pay more attention to the topic of study, establishing associations and making connections between what they see and their prior knowledge (Dueñas and Vargas, 2013). Luchini (2006) also stated that visual stimulus is a practical medium to promote students to talk in language classroom in addition to Brown (2007) who supported this by stating that visual aids can be used in the different stages in teaching and learning to introduce and motivate the study of new topics.

\section{Conclusion}

The impact of CLT in developing communicative competence among students has placed it as one of the most prominent approaches in current language teaching, and the importance of instructional materials in teaching knowledge and reinforcing verbal instruction (Pagcaliwagan, 2015) is undeniable. Materials used in language teaching indeed have roles as a resource for presentation of materials either spoken or written, as a source of activities for learners' practice and communicative interaction, as a reference source for learners on grammar, vocabulary, pronunciation, and as a source of stimulation and ideas for classroom activities (Richards, 2003). In line with the aspiration of Education NKRA, which is to improve student outcomes across the Malaysian school system and to enable access to quality education for all students, the utilisation of the ASSURE model in this study is hoped to bridge the gap between novice and experienced instructors by providing a guideline to ensure quality teaching and learning process in the English speaking classroom.

Developing student's competency in public speaking requires training and activities which take into account the student's current knowledge of the topic. This however, can be overwhelming to students themselves who lack confidence and opportunities to practise public speaking. This pilot study has shown the effectiveness of using the Speak-O-Rama module to increase students' oral proficiency along with employing self-confidence to speak in public at a young age. Indeed, students involved in this study gained much enhancement. The students showed high level of self confidence and motivation upon completion of the module where they dedicated good participation; in fact, the number of students volunteering to speak in front increased from week to week. In conclusion, the module was effective as it greatly contributed towards the speaking skills of the students. It is hoped that this study will help teachers to have a better understanding in selecting and choosing materials, and the process involved in preparing effective instructional materials, particularly focusing on speaking skills. It would be fruitful to pursue further exploration of this module to many other groups of primary school students in order to witness the speaking skills improvement of many other students.

\section{References}

Ahmad Zabidi, A. R. (2005). Ciri-ciri sekolah berkesan: implikasinya terhadap pengurusan sekolah agama. In S.Hussin, S. @ Charil Marzuki, A. Z. Abdul Razak, H. Md Som \& A. Ranee (eds.). Pentadbiran dalam Pembangunan Pendidikan (pp. 75-92). Bentong: PTS Professional Publishing.

Akey, T. M. (2006). School Context, Student Attitudes and Behaviour, and Academic Achievement: An Exploratory Analysis. New York, NY: MDRC.

Al-Hebaish, S.M. (2012). The correllation between general self confidence and academic achievement in the oral presentation course, Theory and practice in language studies, (2) 1, 60-65.

Ampa, A. T., Muhammad Basri, D., \& Andriani, A. A. (2013). The development of contextual learning materials for the English speaking skills. International Journal of Education and Research, 1(9), 1-10.

Baker, J. And Westrup. H. (2003). Essential Speaking Skills: A handbook for English Language Teachers. London: Continuum International Publishing.

Beetham, H. \& Sharpe, R. Eds (2007). Rethinking Pedagogy for a Digital Age. Designing and Delivering E-Learning. London: Routledge.

Bitterlin, G. Johnson, D., Price, D., Ramirez, S., Savage, K.L. (2011). Ventures transition workbook. New York: Cambridge University Press

Brouse, C.H., Basch, C.E., Le Blanc, M.,McKnight, K.R. and Ting Lei. (2010). College students' academic motivation: Differences by gender, class, and source of payment. College Quarterly, (13), 1.

Brown, H. (2000). Personality Factors. Principles of Language Learning and Teaching. New York: Pearson education.

Brown, G. and Yule, G. (1999). Teaching the spoken Language. Cambridge University Press

Carlin, D. \& James, P. (1995). Public Speaking Today, 2nd edition. Illinois: National Textbook Company.

Dabbagh, N. (2002). Web-Based Course Management Tools, In Educational Technology, An Encyclopedia. Santa Barbara, CA: ABC-CLIO. 
Dörnyei, Z. (2005). The psychology of the language learner: Individual differences in second language acquisition. Routledge.

Dueñas, L.T.B. and Chacon Vargas, L.M. (2013). Student-teachers' teaching techniques: Actors in pupils' extrinsic motivation as they speak. Teachers' Professional Development, 15(2), 69-84.

Fachrurrazy. (2012). Teaching English as a foreign language for teachers in Indonesia. Malang: State University of Malang Press.

Fortier, M.S., Vallerand, R.J., and Guay, F. (1995) Academic motivation and school performance: Toward a structural model. Contemporary Educational Psychology, 20, 257-274.

Gustafson, K. L. \& Branch, R. M. (2002). Re-Visioning Models of Instructional Development. Educational Communications and Technology, 45(3), 73-89.

Harmer, J. (1998). How to teach English: an introduction to the practice of English language teaching. New York: Longman

Harris, S. (2009). The relationship Between Self-Esteem and Academic Success among African American Students in the Minority Engineering Program at a Research Extensive University in the Southern Portion of the United States. Doctoral Dissertation. Louisiana State University.

Heinich, R. , Molenda, M., Russell, J.D. (2001). The ASSURE Model, Instructional Media and Technologies for Learning.

Luchini, P. (2006). Enhancing learners' motivation and concern for improving their pronunciation at a translator program in Argentina. HOW, A Colombian Journal for Teachers of English, 13, 125-137.

Maimun Aqsha Lubis. (2015). Effective implementation of the integrated Islamic education. Global Journal AlThaqafah, 5(1), 59-68.

Md Obaydul Hoque, Muhammad Shafi Uddin, \& Muhammad Nazmul Huda. (2015). Reviewing Curriculum of Islamic Education Institutions: A case of Malaysia. Journal of Islam, Law and Judiciary (ISSN 2411-4936), 1(4), 35-54.

Musa, N. C., Lie, K. Y., \& Azman, H. (2012). Exploring English language learning and teahcing in Malaysia. GEMA Online Journal of Language Studies, 12(1), 35-51.

Pagcaliwagan, S. (2015). Assessment of Instructional Materials in Speech and Oral Communication: Basis for Curriculum Enhancement. International Advanced Research Journal in Science, Engineering and Technol ogy, 2(11).

Pierce, J. and Gardner, D. (2004). Self-Esteem Within the Work and Organisational Context: A Review of the Organization-Based Self- Esteem literature. Journal of Management. 30 (5), 591-622.

Rahimah Haji Ahmad, (1998). Educational development and reformation in Malaysia: past, present and future. Journal of Educational Administration, 36, 5 pp. 462 - 475.

Hughes, R. (2006). Spoken English, TESOL, and applied Linguistics: Challenges for Theory and Practice. Great Britain: CPI Antony Rowe.

Richards J. C. (2003). Developing Speaking Activities. From Theory to Practice. Guidelines, (RELC, Singapore), Vol 28, 2, Dec 2006, pp. 3-9.

Richards, J.C. \& Rodgers, T. (1999). Approaches and Method in Language Teaching: Communicative Language Teaching. New York: Cambridge University Press.

Rickheit, G., \& Strohner, H. (Eds.). (2008). Handbook of communication competence (Vol. 1). Walter de Gruyter.

Rubio, F. (2007). Self-Esteem and Foreign Language Learning. Cambridge Scholars Publishing.

Ryan, R.M., and Deci, E.L. (2000). Intrinsic and extrinsic motivations:Classic definitions and new directions. Contemporary Educational Psychology, 25, 54-67.

Tallon, M. (2009). Foreign Language Anxiety and Heritage Students of Spanish: A Quantitative Study. Foreign Language Annals, 42(1), 112-137.

Torres, K. M., and Turner, J. E. (2016). Students' foreign language anxiety and self-efficacy beliefs across different levels of university foreign language coursework. Journal of Spanish Language Teaching, 3(1), 57-73.

Vilímec, E. (2006). Developing speaking skills (Master's thesis). University of Pardubice, Czech Republic. 